\title{
WHY BARZILLAI OF GILEAD (1 KINGS 2:7)? NARRATIVE ART AND THE HERMENEUTICS OF SUSPICION IN 1 KINGS 1-2
}

\author{
Iain W. Provan
}

\section{Summary}

Even if one remains uneasy about the precise direction in which much recent scholarship on biblical narrative has been moving, it is the case that much can be learned from the kind of approaches which have been developed. This paper argues, for example, that the author of 1 Kings 1-2 invites the reader to employ a 'hermeneutic of suspicion' in relation to his story by the artful way in which he tells it; and that the employment of such a hermeneutic enables a deeper grasp of what the story is about than would otherwise be possible.

\section{Introduction}

These are interesting times for those who are concerned with the interpretation of biblical texts, particularly Hebrew narrative texts. Old certainties are under attack. New revolutionaries clamber over the barricades, pronouncing those only recently considered (and considering themselves) as radicals to be, in fact, boringly conservative and quite passé.

It seems just a blink of the eye ago, for example, that the average commentator on Kings thought it an important part of his task to tell his readers quite a bit about the sources from which the book might have been constructed and the editors who might successively have worked upon it. Of the existence of such sources and editors there was really no doubt, even if there was much disagreement about the details. It was simply accepted that there was a greater or lesser degree of incoherence in the text-inconsistencies, repetitions, variations in style and language, and so on-features 
unexpected, it was said, in the work of a single author. Either the person who put Kings together was not a free agent, able to do just as he wished-he was to a greater or lesser extent constrained by the material available to him, and he was unable or unwilling to impose complete consistency upon it. Or (perhaps and) the original work has been expanded by one or more editors, also constrained by what lay before them, they, too, being able to make the text convey their particular message only to a certain extent. What we had in Kings, then, was a composite work, put together over a longer or shorter period of time by a number of authors or editors, its various parts speaking with more or less conflicting voices. Some voices may be louder than others, on such a view; but they are unable entirely to drown out their fellows.

It is hardly surprising, given this general perception of the nature of Kings within the academic community throughout most of the modern period, that scholarly reading of the book as a book in this period should generally have ceased. Thus we have had a plentiful supply of commentaries which tell the reader, on the one hand, what individual pieces of Kings might have meant before they were incorporated into the book; or, on the other, which pieces are 'original' to the book and which are late additions or glosses. 1 There is no shortage of discussion of the historical and cultural background of the various parts of Kings; of the likely geographical location of the various cities mentioned in the text; of the obscurities of OT flora and fauna. ${ }^{2}$ Of the analysis of bits and pieces there has been (and continues to be) no end. Of the reading of a reconstructed narrative of some kind, there has been a little. But of the reading of the book as it stands as a complete story in its Hebrew form (or for that matter its Greek form), there has been, until recently, scarcely any.

${ }^{1} C f$., for example, J. Gray, 1 and 2 Kings (Old Testament Library; 3rd. ed.; London: SCM, 1977); G.H. Jones, 1 and 2 Kings (New Century Bible; 2 vols.; Grand Rapids: Eerdmans, 1984); and S.J. DeVries, 1 Kings (Word Biblical Commentary; Waco: Word Books, 1985).

${ }^{2} \mathrm{Cf}$., for example, M. Cogan and H. Tadmor, 2 Kings (Anchor Bible; Garden City: Doubleday, 1988); and D.J. Wiseman, 1 and 2 Kings (Tyndale; Leicester: IVP, 1993). 
It is into the midst of this conservative consensus that the new radicals have charged with their revolutionary yells. Can repetition not be an aspect of literary artistry, they have asked? Can variation in style and language not have many explanations other than difference in authorship? Is not 'inconsistent' a word which is often used where terms such as 'theologically complex' or 'ironic' would do just as well? Is not the problem, in fact, largely that OT scholars, often lacking general competence in matters literary, and approaching the text with inherited presuppositions about its incoherent nature (among other things), have largely found what they expected to find? And so we have had a succession of books and articles in recent times on the narrative art of the Hebrew Bible, ${ }^{3}$ work which is perceived by many to have been extraordinarily fruitful in revealing the extent of the skill which has been involved in constructing, not only individual stories, but also whole sections of text and entire books. Incoherence tends to dissolve in the course of such analysis; and models of composition which presuppose frustrated or reluctant authors, not fully in control of their material; or incompetent editors, intruding their presence sufficiently that we should notice them, but unable fully to impose themselves; or even multiple scribes, each adding their pennyworth without giving much thought to the question of overall coherence-such models are bound to be called into question.

The commentator who feels the force of such questioning is bound to attempt a commentary which differs from many which have preceded it. ${ }^{4} \mathrm{He}$ will be obliged to make

${ }^{3} C f$., for example, J. Licht, Storytelling in the Bible (Jerusalem: Magnes, 1978); R. Alter, The Art of Biblical Narrative (London: Allen \& Unwin, 1981); M. Sternberg, The Poetics of Biblical Narrative: Ideological Literature and the Drama of Reading (Bloomington: Indiana UP, 1985); D.M. Gunn and D.N. Fewell, Narrative in the Hebrew Bible (Oxford Bible Series; Oxford: OUP, 1993).

${ }^{4}$ The present article arose out of my own work on a new commentary on Kings which will be published in 1995 as 1 and 2 Kings (New International Biblical Commentary; Peabody: Hendricksons). I should like to take this opportunity to thank the staff at Tyndale House for their excellent hospitality during the sabbatical which saw this work completed. 
the attempt even if he feels uneasy about the precise direction in which some of the scholars devoted to the newer approaches are moving. I am not personally very impressed, for example, by the way in which both the newer literary critics and the newer historians tend increasingly (and vocally) to divorce narrative texts from the past which the texts often claim to be speaking about. ${ }^{5}$ Nor am I impressed by the way in which many scholars also tend increasingly (and quite explicitly) to deify the reader in respect of the text that is being read, whether by making the reader the creator of meaning, or by assigning readers the moral duty at all times of exercising a 'hermeneutic of suspicion' in relation to the object of their study. ${ }^{6}$ Yet the

${ }^{5} \mathrm{Much}$ of what is currently being written about the history of Israel, for example, seems to me to reveal a profound failure to grasp the nature of historiography in general-the extent to which all historiography, whether ancient or modern, has a story-like quality; the extent to which all writing or speaking about the past involves turning happenings and people into events and characters; the extent to which all historiography is also in some sense ideological in character, involving selection and interpretation by authors intent on persuading their readership in some way. The fact that books like Kings may in some sense be 'ideological' and 'story-like' (as modern literature tends to describe them: $c f$., for example, N.P. Lemche, Ancient Israel: A New History of Israelite Society, The Biblical Seminar 5 [Sheffield: JSOT Press, 1988]; G.W. Ahlström, The History of Ancient Palestine from the Palaeolithic Period to Alexander's Conquest, JSOT Sup 146 [ed. D.V. Edelman; Sheffield: JSOT Press, 1993]; P.R. Davies, In Search of 'Ancient Israel', JSOT Sup 148 [Sheffield: JSOT Press, 1992]; T.L. Thompson, Early History of the Israelite People from the Written and Archaeological Sources [Studies in the History of the Ancient Near East 4; Leiden: Brill, 1992]) does not ipso facto render them incapable of speaking truly about the past, any more than this is necessarily true of other texts which plainly have historiographical intent. For a detailed discussion of the point, $c f$. my soon to be published JBL paper, 'Ideologies, Literary and Critical: Reflections on Recent Writing on the History of Israel'.

6In the extreme form of this position, we find the assertion simply that there is no such thing at all as 'the meaning of the text': readers create their own meanings. There is not, in fact, any such thing as a text: there is simply a primeval chaos of words and phrases waiting for the divine actor (i.e., the reader) to bring it to order. It is difficult to explain the popularity of this position, since it is self-evidently both incoherent (if readers create their own meanings, how do they know the meaning of statements like 'readers create their own meanings'?) and politically 
commentator who is aware of the debate about the relationships between texts and history, and recognises the sharpness of many of the questions raised in that debate, is bound to approach the task of commentary with literary questions uppermost in the mind first of all. It is inevitable that the attempt to understand the literature as literature will precede the attempt to understand it in relation to the past to which it refers. By the same token, the commentator who has listened to the debate about the nature of our biblical texts as literature is bound to approach the task of commentary with heightened sensitivity to the presence of diverse voice, ideological conflict and the like within the text. Even if a systematic programme of suspicious reading is eschewed, there will remain an awareness that it is possible, for example, for authors themselves to invite suspicion by the artful way in which they tell their story. It is possible for authors to invite their readers to ponder individual statements in the light of that story as a whole, and through suspicious reflection upon those statements, particularly statements made by certain of

unwise (what is the purpose of departments of Hebrew and Old Testament Studies in these days of market-forces ideology, if there are no Hebrew texts and their meanings to be studied?). The more moderate form of the argument runs as follows. Biblical narrative texts do have meanings, and their authors do have intentions, but these texts are nevertheless ideological entities. The task of the reader is not, therefore, simply to interpret what the authors are saying, and certainly not simply to accept it. Readers, rather, conscious of their own competing ideologies, must bring these same ideologies to the text and look for ways of making connections with the text at some level other than its surface meaning. The reader-as-consumer (deciding whose story to tell, and with what kind of meaning attached to it) must begin with a 'hermeneutics of suspicion', moving on from there to penetrate beneath the surface meaning of the text to what is really going on, to lay it bare for what it is, and then to re-tell the story in more acceptable, indeed more politically correct terms. Again, it must be asked whether those aboard the good ship biblical scholarship can safely cut the anchor of authorial intention in this way, and still be able to claim that the ship has any real direction. If the text becomes simply the tool of this or that crusade-is talked about in terms of what it should have said rather than what it does say-then ultimately the text is dispensable, and will not sustain the study which used to be centred around it. 
their characters, to come to a deeper understanding of what is going on overall. It is possible, then, if this is what is happening in the text, for a hermeneutic of suspicion to be employed, not as a counter-reading strategy, but as a strategy which aims at arriving at a fuller understanding of authorial intent. It is this possibility which I would like to explore in the present paper, taking as my example the story in 1 Kings 1-2, and beginning with the crucially important section of this story in 1 Kings 2:59.

\section{1 Kings 2:5-9}

To those with an interest in the artistic qualities of a text, rather than simply and naively in the text as 'telling one how it was', what is immediately striking about this passage is the rather careful way in which it appears to have been constructed - a fact unsurprising to those who generally know the Hebrew text of Kings well, and are conscious of the very deliberate way in which its story is told. Three characters are mentioned here. In the midst stands Barzillai of Gilead, whom David commends in relatively few words to Solomon's care. On either side of Barzillai stand Joab and Shimei. Their sins and their hoped-for fates are described at much greater length; indeed, at approximately equal length. They are also described in rather similar terms: note the common emphasis on guilt; on Solomon's need for wisdom in dealing with them; on bringing their grey heads down to Sheol.

Why these three men? And why these three men in this order? For it is not quite the chronological order, so far as the narrative of Samuel is concerned. Joab comes first in that narrative, certainly; but Shimei's cursing of David is narrated in 2 Samuel 16:5-14, whereas we are not told of Barzillai's kindness until 2 Samuel 17:27-29. The question thus arises: is there a particular reason, from the point of view of the narrative of Kings, why 1 Kings 2:5-9 has been structured in the way it has, with faithful Barzillai located in the midst of these villains whom David now wishes to see disposed of? Is there a point? I think there is; but to get to it, we have to give broader 
consideration in the first instance to what David is saying here, and to the question of how his words are to be read in the light of just that preceding story in Samuel (and earlier in 1 Kings) which they recall. And here we return to the hermeneutics of suspicion. Are we supposed to take David's words at face value?

The question is most pointed in relation to what the king has to say about Joab in v. 5. Now it is, of course, quite true that Joab had killed both Abner (2 Sa. 3:22-30) and Amasa (2 Sa. 20:4-10); and David seems to be saying that in so doing, he had also done something to David himself. 2 Samuel 3:28-29 suggests that, in the case of Abner, Joab had in fact brought the danger of divine retribution on David and his house, through association with the awful deed. Certainly that is how Solomon interprets the situation to Benaiah in 1 Kings 2:31-33. Joab is to be killed so as to clear Solomon and his father's house of the guilt of the innocent blood that Joab shed (v. 31), both Abner's and Amasa's.

This is all well and good; but there are some questions to be asked. Hitherto, David has apparently not felt at all compelled to take any action against Joab of the sort now being contemplated. He has been content simply to state his innocence and to leave the rest to God (2 Sa. 3:28-29: 'I and my kingdom are forever guiltless... for the blood... May it fall upon the head of Joab...'). Notice the somewhat 'hands-off' approach being adopted here, in contrast to the rather more pro-active stance in 1 Kings 2 . We are bound to ask, then: how seriously concerned can David have been about this bloodguilt? Apparently not sufficiently so, that he had hitherto been prepared to rid himself of someone utterly loyal to him, someone who frequently took the initiative on his behalf and for his good (e.g., 2 Sa. 14, in the reconciliation of Absalom; 19:1-8, in his rebuke of David after Absalom's death). Joab was, after all, a very useful person to have around, especially when David wanted someone killed without any blame being attached to the king, as in the case of Uriah (2 Sa. 11:15)another instance when David seems quite unconcerned about blood-guilt. 
We may wonder, then, about the sincerity of what he has to say to Solomon, particularly when we remember that the circumstances in which Joab carried out these killings were not quite so unambiguous as David's speech here makes them appear. In one sense Joab's killing of Abner was itself bloodvengeance for the death of Joab's brother; and who is to say that he did not sincerely believe that Abner had come to Hebron to spy (2 Sa. 3:25), and was thus committing an act of war, and not of peace? The circumstances in which Amasa, so recently the commander of Absalom's rebel forces (2 Sa. 17:25), mysteriously fails to collect the men of Judah in time to pursue the rebel Sheba (2 Sa. 20:4-5) are even less clear. Is he simply incompetent, or is his delay deliberate? And is Joab really to blame, in view of what he knows of David's character thus far in the narrative, if he interprets David's implicitly critical words in 2 Samuel 20:6 ('Now Sheba the son of Bichri will do us more harm than Absalom') as signalling his desire that Amasa should disappear? Joab had, after all, built a career on having people killed for David's benefit, whether at his express command or not ( $c f$. the killing of Absalom in 2 Sa. 18:14-15); and there is certainly no mention of any concern on David's part over Amasa's death before we reach 1 Kings 2:5 (note the deafening silence in 2 Sa. 20). All in all, then, it is difficult for the reader who knows the story as it has been told so far to believe that blood-guilt is the real reason why loyal Joab is now, at this very late date, to be done away with. It is difficult indeed to take David's words in v. 5 at face value.

It does not become any easier to do so if we pursue the story of Joab into the latter part of chapter 2. It is here, of course, that we read of the steps taken by Solomon to remove exactly those people mentioned to him by David, plus a couple more for good measure. Adonijah is the first to bite the dust, closely followed by Abiathar and Joab. There is, of course, no evidence that Abiathar and Joab had anything whatever to do with Adonijah's initiative in regard to Abishag, of which we read in 1 Kings 2:12 ff. They are apparently simply pronounced guilty by association. Abiathar is banished to his family estate in Anathoth-treated very leniently, in fact, in comparison with the others in the story. A reason is found for such leniency 
(v. 26), although it is not a very convincing one. ${ }^{7}$ Joab could also have cited a long history with David in mitigation of his crimes, had anyone been concerned to listen. The authors, indeed, themselves remind us of this history with that curious phrase 'though not with Absalom' in v. 28. This is very interesting. Why mention Absalom here at all, if not to help us to recall that this is Joab's 'first offence' in an otherwise blameless career, from the point of view of loyalty to David? And why give us this reminder at all, in this context, if they are not by the way in which they tell the story inviting us to be sceptical of what their characters are saying?

What really differentiates Abiathar from Joab, of course, is not their histories at all, but their importance in Solomon's mind. Solomon is simply not very interested in Abiathar, whereas he is utterly determined to settle with Joab. No doubt that is why Joab, upon hearing what had happened to Adonijah and Abiathar, flees to the tent of the LORD and takes hold of the horns of the altar (v. 28). He knows that he can expect no mercy: that is why he refuses to come out (v. 30). Perhaps he does not count on Solomon being just as ruthless as he is-prepared even to have someone killed in the place of sanctuary. ${ }^{8}$ If so, he has miscalculated. Benaiah is dispatched to the tent; and with a cool obedience to his king which is worthy of Joab at his best (or worst), he strikes him down at the sacred altar (v. 34).

There is, in truth, something of poetic justice in all of this. Joab had lived by the sword, killing (among others) two army commanders who just happened to be his professional rivals; now he dies by the sword, and is immediately replaced

${ }^{7}$ This is so particularly when it is realised that Abiathar is, in fact, never described in the Hebrew text of Samuel as carrying the ark before David. I draw a veil here over discussion of ephods and the like.

8Joab's 'guilt' may or may not be regarded by the reader as having been established. What is certain, however, is that in ordering his execution beside the altar, Solomon himself is guilty of breaking the law. Ex. 21:12-14 quite clearly states that a murderer is to be taken away from the altar and put to death; and Benaiah certainly seems to be aware of this (cf. his instinctive interpretation of Solomon's first command in $1 \mathrm{Ki}$. 2:29 as implying execution outside the sanctuary, v. 30). So who is really 'guilty?' 
by his killer as commander of the army (v. 35). Yet we must ask of Solomon as we asked of David: are we to take the king's rhetoric in vv. 31-33 seriously? Is Joab really being killed at this point in Israel's history because of an overwhelming desire to clear David's house of blood-guilt (v. 31)? We have already seen reason to question this line. What are we to make now of Solomon's claim to occupy the high moral ground in relation to Joab, this waxing lyrical about the difference between Joab's house and his own? Again, remember the story. Solomon is a king himself born of a union forged in innocent blood (2 Sa. 1112) - a union made possible, indeed, through the obedience of the very man being hounded in this passage. Are we really supposed to bracket this knowledge out, suspend our disbelief, in fact, as we listen to such Solomonic sermonising? Or are we being asked precisely to set words and actions alongside each other, and come to our own conclusions about what is going on here?

\section{The Old King and the New King}

What I am suggesting is that it is very difficult indeed for anyone who has grasped the story of Samuel-Kings so far to believe in the justification which David and his son are offering for Joab's murder. The way in which the story is told undermines the narrative which these two characters offer us. That is true of the particular passages we have looked at so far; but it is also true of the way in which 1 Kings 1-2 is narrated in general. For it could not be said, I think, that either David or Solomon is presented in a very favourable light throughout.

Here we have the dying king, David, now out of touch with reality, now fully in control, with a curiously ambivalent attitude to oaths and a selective memory. His oath to Bathsheba he stands by; his oath to Shimei he chooses to 'interpret', so as to allow Solomon to kill him ('I may not kill him, but you may do so'). The loyalty of Barzillai he remembers, for it costs him nothing to do so; the loyalty of Joab he chooses to forget, because to remember would be to make 
evident that his conscience about blood-guilt has been found late and conveniently.

Here, on the other hand, we have the new king, Solomon. He, too, takes oaths seriously when it suits him to do so, and interprets them ungenerously otherwise ( $c f$. his murder of Shimei). ${ }^{9} \mathrm{He}$, too, has a selective memory, as both his treatment of Abiathar and Joab, and his speech in 1 Kings 2:3133 reveal. The general impression throughout, indeed, is of a fairly sordid story of power-politics thinly disguised as a morality tale. So tortured are the attempts, however, to convince us that the men who died did so because they deserved it, that we cannot but be aware of their speciousness. We are invited to be suspicious, and to ask what the real reason for David's advice about Joab and the others really was. Why is Joab to be killed now, at precisely this moment in Israel's story?

The clue is to be found, I suggest, not so much in the religious significance of the actions which are described in vv. 5-9 of 1 Kings 2, but in their political significance. What is it that we are really being reminded of in these verses? We are being reminded of two occasions when David's attempts at reconciliation between two warring factions in Israel were undermined by Joab's independent activity (on the one hand, reconciliation between Saul's supporters and David; on the other, between Absalom's supporters and David). Is the real issue here, then, not simply that Joab is too dangerous to be allowed to live in Solomon's united kingdom once David is

\footnotetext{
9Solomon's willingness to ignore the letter of the law when it suits him (in the case of Joab) only throws into sharper relief his vindictive treatment of Shimei in $1 \mathrm{Ki}$. 2:36-46, where the letter of the law is crucial. Whether Shimei interpreted Solomon's instructions in $1 \mathrm{Ki}$. 2:36-37 to mean that he must never under any circumstances leave Jerusalem is not clear. It would be natural, rather, to interpret these words (particularly in view of the mention of Kidron in 2:37) as being intended specifically to prevent a potential troublemaker from operating within his own power-base in Benjamin. In fact, Shimei quite clearly does not cross Kidron in vv. 39-40-the silence of the text on this point is deafening. He is going westward to Gath, not eastward to Bahurim. But Solomon takes the opportunity to have him executed anyway (v. 46). David's instructions have been carried out. Solomon has proved himself to be a 'wise' king (2:9).
} 
gone? Is that not perhaps the real reason for the timing of the action? Joab is simply too much a man of the Judean past; he has already shown that through his allegiance to Adonijah. 10 Joab is not a man who will be content with Solomon's kingship, and make the government of a united Israel easy. He must therefore be removed; and the issue of blood-guilt becomes simply a convenient justification for his death.

Now if it is indeed concern for 'the good of the state' which lies behind David's words in 2:5-6, then we 'may well have the explanation for why it is that these three men in particular-Joab, Barzillai and Shimei-have been selected for consideration at all, and placed in the order they have. For Shimei, too, has been from the very first, like Joab, a

${ }^{10}$ I understand the conflict in ch. 1 to be largely conflict between old, Judah-based comrades of David from the Hebron days, and newer, Jerusalem-based associates. Adonijah was, of course, born in Hebron (2 Sa. 3:2-5), while Solomon was born in Jerusalem (2 Sa. 5:13-16). Joab appears early on as David's right hand man and the commander of his troops (e.g., 2 Sa. 2-3; 11-12; 14; 18); Abiathar is also one of David's oldest associates (1 Sa. 22:20-23). These are men with deep roots in David's Judean past. It seems likely, in view of the fact that the guest list for Adonijah's feast (1 Ki. 1:9) mentions only those royal officials who were men of Judah (and not also Israel), that their support for Adonijah represents at least in part a commitment to history and tradition, and to the continuing influence of Judeans at the centres of power. By contrast, only Benaiah of the individuals named in the opposing group has any claim to such a long-standing association with David (1 Ki. 1:8; cf. 2 Sa. 20:23; 23:20-23), although we must include here also the men who made up David's special guard (the 'mighty men' of 2 Sa. 23:8-39). Aside from these men and Rei (otherwise unknown), we find mentioned in this group Shimei, who does also appear in $2 \mathrm{Sa}$. (16:5-14), but only as an antagonist of David from the house of Saul; and Nathan and Zadok, neither of whom appear in the narrative before 2 Sa. 7:2 and 8:17 respectively (i.e., after David's move from Hebron to Jerusalem, 2 Sa. 5:6-10). It seems reasonable to assume that what unites at least these last three around the Jerusalem-born Solomon is a commitment to the present in contrast to the past-to a kingdom in which Jerusalem is centrally important and the northern tribes are more likely than under Adonijah to play their full part. We must understand the events of $1 \mathrm{Ki} .1-2$, in other words, in the light of the Judah-Israel tensions already evident in Samuel (e.g., 2 Sa. 20), and soon to explode into schism again in $1 \mathrm{Ki} .12$ (cf., in particular, $2 \mathrm{Sa}$. 20:1 and $1 \mathrm{Ki} .12: 16$ ) 
partisan-though this time of the north, and not the south (2 Sa. 16:5-14; 19:20). It is, indeed, in the context of a (failed) attempt at national reconciliation (2 Sa. 19:9-20:22) that David spares his life-an attempt, we may note, to which neither of the sons of Zeruiah are apparently sympathetic (19:21-23; 20:810). Shimei, like Joab, represents an element within the kingdom likely to be hostile to unity under a Davidic king, his implied support for Solomon in 1 Kings 1:8 notwithstanding.11 It is interesting, then, that between these disruptive elements from Judah and Israel (2:5-6; 2:8-9), hostile to harmony, has been positioned Barzillai from Gilead in Transjordan (2:7): the very model of dutiful service to his king, service which is rewarded in peaceful fellowship around the king's table. Is it possible that the passage has been structured precisely so as to present Solomon with an ideal (peaceful community), and to suggest to him what kind of people from David's past-on both sides of that past-have to be removed if this ideal is to be attained (i.e., those likely to disrupt peaceful community)? ${ }^{12}$

${ }^{11}$ Commentators have been reluctant to identify the Shimei mentioned in $1 \mathrm{Ki}$. 1:8 with the man of the same name in $2 \mathrm{Sa}$. 16:5-14 and $1 \mathrm{Ki}$. 2:8-9, 36-46, though why this should be is something of a mystery. The wording of $1 \mathrm{Ki}$. 2:8 ('...you have with you Shimei son of Gera...') clearly implies that it is indeed this same Shimei who has joined Solomon's party, and this is the natural assumption of the reader who has read thus far in Samuel-Kings. His presence for the moment in the Solomonic party is sufficiently explained by antipathy to the Judean Adonijah, a king not likely to favour someone from Saul's clan. Solomon is perhaps nothing more to him than the lesser of two evils.

${ }^{12}$ It is certainly interesting in this connection to note the way in which the 'king's table' (1 Ki. 2:7) reappears later in the Solomon story, in $1 \mathrm{Ki}$. 4. It is the very centre, in fact, of the account which we are given there of Solomon's glorious and peaceful rule over Judah/Israel and the nations (cf. esp. 4:27): a period which Solomon can describe to Hiram in $5: 4$ [5:18] as one in which there is rest on every side, all enemies subdued. The symbolic value of the king's table to the authors of Kings is indeed illustrated not just by that passage, but also by $2 \mathrm{Ki}$. 25, where the eventual end of Davidic rule over Judah/Israel, the obverse of Solomonic splendour, is given pathetic illustration by the fact that king Jehoiachin sits at the table of the king of Babylon ( $2 \mathrm{Ki}$. 25:29). The nations no longer flock to supply David with food. David is instead to be found as a dependant upon them. 


\section{Conclusion}

Consciousness of narrative art, I have argued, alerts us to questions which a hermeneutics of suspicion can help us to answer. The art should be the author's, however, and not the reader's; the suspicion should be invited and not imposed. Sensitivity to art and invitation in the case of 1 Kings 1-2 leads us to a rather different reading of the end of the David story and the beginning of the Solomon story than that at which we might otherwise have arrived. 